Pesq. Vet. Bras. 36(3):209-215, março 2016 DOI: $10.1590 / \mathrm{S} 0100-736 \mathrm{X} 2016000300010$

\title{
Vitrification of bovine preantral follicles with dimethylsulfoxide and sucrose plus $\alpha$-tocopherol ${ }^{1}$
}

\author{
Carolina R. Jimenez ${ }^{2 *}$, Jurandy M. Penitente-Filho ${ }^{3}$, Ciro A.A. Torres ${ }^{3}$, Amanda M. \\ Medeiros $^{4}$ and Leandro S. Silva ${ }^{4}$
}

\begin{abstract}
Jimenez C.R., Penitente-Filho J.M., Torres C.A.A., Medeiros A.M. \& Silva L.S. 2016. Vitrification of bovine preantral follicles with dimethylsulfoxide and sucrose plus $\boldsymbol{\alpha}$-tocopherol. Pesquisa Veterinária Brasileira 36(3):209-215. Laboratório de Nutrição Animal, Centro de Energia Nuclear a Agricultura, Universidade de São Paulo, Av. Centenário 303, Cx. Postal 96, Piracicaba, SP 13400-970, Brazil. E-mail: zoocaro@hotmail.com

The objective of this study was to evaluate the vitrification of bovine preantral follicles with dimethylsulfoxide (D) and sucrose (S) plus $\alpha$-tocopherol $5 \mathrm{mmol} / \mathrm{L}$ (T5) or $10 \mathrm{mmol} / \mathrm{L}$ (T10) and, evaluate the thawed with minimal essential medium (m) with or without sucrose (s). Ovaries of cows were collected from slaughterhouse for the experiment I $(n=66)$ and II $(n=51)$. In the laboratory ovarian fragments were randomly assigned either to fresh control and 8 vitrification treatments (Controle and Dm; Dms, DSm; DSms; DST5m; DST5ms; DST10m; DST10ms). Ovarian fragments were placed in vitrification solution (5 $\min )$ and immersed in liquid nitrogen $\left(-196^{\circ} \mathrm{C}\right)$, after a week, the fragments were thawed and analyzed. In the experiments I, preantral follicles were morphologically observed for histological evaluation, (normal; degenerated and developing of stage). In the experiment II, preantral follicles were mechanically isolated from ovarian tissue and examined with trypan blue, where dead and live corresponded to stained or non-stained. The treatments DSm, DSms and DST10m were effective in preserving the morphology in situ. However, the viability of isolated preantral follicles after vitrification remained high only in treatment DST10m. Thus, DST10m preserves survival rates and morphological integrity during vitrification of bovine preantral follicles.
\end{abstract}

INDEX TERMS: Antioxidants, dimethylsulfoxide, cryopreservation, cryoprotectant, oocyte, granulosa cells.

RESUMO.- [Vitrificação de folículos pré-antrais bovinos com dimetilxulfoxido e sacarose adicionado de $\alpha$-tocopherol.] Os objetivos deste estudo foram avaliar a vitrificação de folículos pré-antrais bovinos com dimetilsulfóxido (D) e sacarose (S) adicionando $\alpha$-tocoferol $5 \mathrm{mmol} / \mathrm{L}$ (T5) ou $10 \mathrm{mmol} / \mathrm{L}$ (T10) e, avaliar o aquecimento com meio essencial mínimo (m) com ou sem sacarose (s). Ovários

\footnotetext{
${ }^{1}$ Received on March 23, 2015.

Accepted for publication on November 29, 2015.

${ }^{2}$ Laboratório de Nutrição Animal, Centro de Energia Nuclear a Agricultura, Universidade de São Paulo (USP), Avenida Centenário 303, Cx. Postal 96, Piracicaba, SP 13400-970, Brazil. *Corresponding author: zoocaro@ hotmail.com

${ }^{3}$ Departamento de Zootecnia, Laboratório de Fisiologia e Reprodução Animal, Universidade Federal de Viçosa (UFV). Av. P.H. Rolfs, Viçosa, MG 36570-900, Brazil. E-mails: penitentefilho@yahoo.com.br, ctorres@ufv.br

${ }^{4}$ Departamento de Veterinária, UFV, Av. P.H. Rolfs, Viçosa, MG 36570-900, Brasil.E-mails: amanda.medeiros@ufv.br, leandro.swerts@hotmail.com
}

de fêmeas bovinas foram coletados de abatedouro, para o experimento I $(n=66)$ e II $(n=51)$. No laboratório fragmentos ovarianos foram distribuídos aleatoriamente para o controle fresco e 8 tratamentos de vitrificação (Controle e Dm; Dms, a DSm; DSms; DST5m; DST5ms; DST10m; DST10ms). Os fragmentos ovarianos foram colocados na solução de vitrificação (5 min) e imersos em nitrogênio líquido $\left(-196^{\circ} \mathrm{C}\right)$. Após uma semana os fragmentos foram aquecidos e analisados. No experimento I, folículos pré-antrais foram observados morfologicamente para avaliação histológica (normal, degenerados e estádio de desenvolvimento). No experimento II, folículos pré-antrais foram mecanicamente isolados do tecido ovariano e examinados com o azul de trypan, observando mortos e vivos corados e não corados respetivamente. Os tratamentos a DSm, DSms e DST10m foram eficazes na preservação da morfologia in situ. No entanto, a viabilidade de folículos pré-antrais isolados após a vitrificação manteve-se elevada apenas no tra- 
tamento DST10m. Assim, DST10m preservou as taxas de sobrevivência e integridade morfológica durante a vitrificação de folículos pré-antrais bovinos.

TERMOS DE INDEXAÇÃO: Antioxidantes, dimetilsulfóxido, criopreservação, crioprotetor, oócito, células granulosas.

\section{INTRODUCTION}

The main problem of cryopreservation of oocytes is associated to the movement of water and intra or extracellular cryoprotectant during cryopreservation. Alternatively, the preantral follicles surface area in relation to the volume is large, providing excellent exchange of substances. Besides being smaller than the mature oocytes, these oocytes are less differentiated, possess fewer organelles, lack pellucida zone and cortical granules, besides being less metabolically active (Campebell et al. 1999). All these features are potentially beneficial to cryopreservation (Oktay et al. 1998) and thus preantral follicles are regarded as an important target of cryopreservation programs.

Generally, the cryopreservation protocols comprise the steps of exposure to the cryoprotectant, cooling, storage, thawing and removal of the cryoprotectants. Exposure to the cryoprotectants, also known as equilibrium period, is the time required for of cryoprotectants penetration or infusion into cells and,or, tissues (Ernst et al. 2010). This is a very important stage and is strongly influenced by cryoprotectants concentration, time and temperature which is performed the exposure (Rodrigues et al. 2010). The vitrification cooling rate is extremely rapid, ranging around 20000 to $40000^{\circ} \mathrm{C} / \mathrm{min}$ (Lin et al. 2008), and as a result, the water goes from liquid to a vitreous state without the formation of intracellular ice crystals (Yeoman et al. 2005). Finished cooling, the sample is stored, usually in liquid nitrogen $\left(-196^{\circ} \mathrm{C}\right)$ until the moment from the thawing. During thawing, undesirable changes may occur in the cells, due to chemical (oxidation) or physical (recrystallization, volume changes) (Hui et al. 2004). Thus, the thawing time, the substances and concentrations used for the removal of cryoprotectants are important steps in the process of cryopreservation.

Different cryoprotectants have been used in combination, with the possibility of optimizing protocols. Rodrigues et al. (2014) demonstrated that ovarian tissue can be frozen using intracellular cryoprotectant as ethyleneglycol, propanediol or dimethylsulfoxide, and can be combined with intra or extracellular cryoprotectant as sucrose in protocols of female gametes, acting as a buffer against osmotic stress during removal of the intracellular cryoprotectant (Demirci et al. 2003). Moreover, in the process of cryopreservation may occur increased of the reactive oxygen species (ROS) that can affect the balance between pro- and anti-oxidant factors in a biological system, leading to lipidic peroxidation (Romero et al. 1998) and, consequently, cellular death. The $\alpha$-tocopherol reduces generation of free radicals and removes them when formed (Souza et al. 1999). The most important biological function of $\alpha$ - tocopherol is to protect cell membrane from lipidic peroxidation, avoiding irreversible damages and cellular death (Wang et al. 2002). Thus, since oxidative stress can be one of the factors involved in apoptosis and, or, follicular atresia, the use of antioxidants may contribute for the success of vitrification of preantral follicles.

Therefore, the purpose of this study was (1) to evaluate the vitrification technique in bovine ovarian tissue, testing the effects of dimethylsulfoxide, sucrose and $\alpha$-tocopherol and (2) to evaluate the effect the thawing with minimal essential medium with or without sucrose.

\section{MATERIALS AND METHODS}

Collection of ovaries. Ovaries $(n=117)$ were collected in a slaughterhouse. In the experiment I, 66 ovaries were used to study the morphology of preantral follicles in situ. For Experiment II, 51 ovaries were used to evaluate the viability of isolated preantral follicles. All collected ovaries were washed in $70 \%$ alcohol for 10 s and then rinsed twice in saline solution ( $\mathrm{NaCl} 0.9 \%$; Sigma/vetec ${ }^{\circledR}$ Brazil), supplemented with streptomycin sulfate $\left(50 \mathrm{mg} / \mathrm{L}\right.$; Sigma/Vetec ${ }^{\circledR}$ Brazil). Thereafter, ovaries were transported to the laboratory at $4^{\circ} \mathrm{C}$, cut into fragments of approximately $9 \mathrm{~mm}^{3}$ and assigned to nine treatments: a fresh control and eight vitrification treatments (Table 1).

Vitrification and thawing. Ovarian fragments were placed in cryotubes with $1.8 \mathrm{~mL}$ of vitrification solution, followed by an equilibration period of $5 \mathrm{~min}$ at room temperature, time sufficient for ovarian fragments are kept in touch with all components of diluent without causing toxicity. Then the tubes were immersed vertically in liquid nitrogen $\left(-196^{\circ} \mathrm{C}\right)$ and stored for one week. After of one cryostorage week, all cryotubes were removed, exposed to room temperature $\left(25^{\circ} \mathrm{C}\right)$ for $1 \mathrm{~min}$, and then immersed in a water bath $\left(37^{\circ} \mathrm{C}\right)$ until the vitrification solution was completely thawed. The cryoprotectant was removed from the ovarian cortex fragments in three washings with MEM or MEM with decreasing sucrose concentrations $(0.50$, $0.25,0.0 \mathrm{~mol} / \mathrm{L}$ of sucrose), for $5 \mathrm{~min}$ each. Then, the fragments for histology were fixated in $4 \%$ paraformaldehyde for $12 \mathrm{~h}$.

Histology. After fixation, the fragments were dehydrated in increasing concentrations of alcohol, diaphanized in xylene, embedded in paraffin and cut into sections $(5 \mu \mathrm{m}$ thickness). The slides were stained with hematoxylin and eosin (Martinez-Madrid et al. 2004) and a total of 50 preantral follicles per slide were examined under an optical microscope (400x; Olympus BX60, Japan) in 30 replications (1500 preantral follicles per treatment).

Classification of preantral follicles. Ovarian fragments (fresh control and vitrification treatments) were analyzed and classified as primordial follicles with spherical or ovoid oocytes completely surrounded by a single layer of flattened and some cuboid-shaped granulosa cells (GCs); the primary follicles were described as spherical oocytes with a single layer of cuboid-shaped GCs; and the secondary follicles as spherical oocytes with two or more layers of cuboid-shaped GCs. The qualitative evaluation of the follicles was based on the integrity of the oocyte and the GCs. The follicles were classified morphologically as: normal - follicles containing intact oocytes and GCs; type I degenerated follicles - follicles with cytoplasmic shrinka- 
Table 1. Designation of treatments, fresh control and vitrified and thawed fragments

\begin{tabular}{cccccc}
\hline Treatment* & \multicolumn{2}{c}{ Vitrification solution } & \multicolumn{2}{c}{ Thawing solution } \\
\cline { 2 - 6 } & $\begin{array}{c}\text { Intracellular } \\
\text { cryoprotectant }\end{array}$ & $\begin{array}{c}\text { Extracellular } \\
\text { cryoprotectant }\end{array}$ & Antioxidant & $\begin{array}{c}\text { Base } \\
\text { medium }\end{array}$ & $\begin{array}{c}\text { Extracellular } \\
\text { cryoprotectant }\end{array}$ \\
\cline { 2 - 6 } & $5 \mathrm{~mol} / \mathrm{L}$ & $0.5 \mathrm{~mol} / \mathrm{L}$ & $5 \mathrm{mmol} / \mathrm{L}$ & $\mathrm{mL}$ & $0.50,0.25$, \\
& & $10 \mathrm{mmol} / \mathrm{L}$ & & $0.0 \mathrm{~mol} / \mathrm{L}$ \\
\hline
\end{tabular}

\begin{tabular}{llclll}
\hline Control & & & & & \\
Dm & Dimethylsulfoxide & - & - & MEM & \\
Dms & Dimethylsulfoxide & - & - & MEM & Sucrose \\
DSm & Dimethylsulfoxide & Sucrose & - & MEM & \\
DSms & Dimethylsulfoxide & Sucrose & - & MEM & Sucrose \\
DST5m & Dimethylsulfoxide & Sucrose & $\alpha$-tocopherol 5 & MEM & \\
DST5ms & Dimethylsulfoxide & Sucrose & $\alpha$-tocopherol 5 & MEM & \multirow{2}{*}{ Sucrose } \\
DST10m & Dimethylsulfoxide & Sucrose & $\alpha$-tocopherol 10 & MEM & \\
DST10ms & Dimethylsulfoxide & Sucrose & $\alpha$-tocopherol 10 & MEM & Sucrose
\end{tabular}

\footnotetext{
* Vitrification solution in uppercase. Thawed solution in lowercase. Dm = Dimethylsulfoxide thawed with minimal essential medium (MEM); Dms = Dimethylsulfoxide thawed with MEM + sucrose; DSm = Dimethylsulfoxide + sucrose thawed with MEM; DSms = Dimethylsulfoxide + sucrose thawed with MEM + sucrose; DST5m = Dimethylsulfoxide + sucrose $+\alpha$-tocopherol $5 \mathrm{mmol} / \mathrm{L}$ thawed with MEM; DST $5 \mathrm{~ms}=$ Dimethylsulfoxide + sucrose $+\alpha$-tocopherol $5 \mathrm{mmol} / \mathrm{L}$ thawed with MEM + sucrose; DST10m $=$ Dimethylsulfoxide + sucrose $+\alpha$-tocopherol $10 \mathrm{mmol} / \mathrm{L}$ thawed with MEM; DST10ms $=$ Dimethylsulfoxide + sucrose $+\alpha$-tocopherol $10 \mathrm{mmol} / \mathrm{L}$ thawed with MEM + sucrose.
}

ge and/or a pyknotic oocyte nucleus; type II degenerated follicles - follicles with oocyte degeneration accompanied by GCs disorganization (Basso \& Esper 2002).

Mechanical isolation and viability analysis. Ovarian fragments were finely cut with a scalpel blade and placed in $50 \mathrm{~mL}$ tubes with $10 \mathrm{~mL}$ of MEM plus $5 \%$ bovine serum albumin and mechanically dissociated by repeated pipetting $(1000$ and $500 \mu \mathrm{L})$. Thereafter, the suspension was filtered twice through nylon mesh (300 and $106 \mu \mathrm{m}$, respectively). In each $100 \mu \mathrm{L}$ of suspension medium containing isolated preantral follicles $5 \mu \mathrm{L}$ of trypan blue $\left(0.4 \%\right.$; Sigma/Vetec ${ }^{\circledR}$, Brazil) was added. Follicles were classified as viable or non-viable, when non-stained or blue-stained, respectively, under an inverted microscope (400x; Olympus, Japan). Fifty preantral follicles were observed per treatment with 30 replicates $(1,500$ preantral follicles per treatment).

Statistical analysis. The data of the morphological (normal, type I and II degenerated) of preantral follicles were subjected to analysis of variance (f test, $\mathrm{P}<0.05$ ), and means were compared by Tukey's test (SAS/2002). The effects of vitrification on the morphological of each development stage (primordial, primary and secondary) and the viability of isolated preantral follicles were arranged in contingency tables and analyzed by chi-square test ( $\mathrm{df} 1=$ 3.84; $\mathrm{P}=0.05$ ).

\section{RESULTS}

Experiment I: In situ morphology of bovine preantral follicles after vitrification

A total of 13,500 preantral follicles were analyzed (1,500 follicles per treatment), following the distribution of normal, type I and II degenerated, respectively, in primordial follicles $(56.8 \%, 28.1 \%$ and $15.1 \%)$, primary follicles (39.8\%, 35.4\% and $24.8 \%)$ and secondary follicles $(30.4 \%$, $49.6 \%$ and $20 \%$ ) (Fig.1). There were no differences ( $\mathrm{P}>0.05$ ) between control and DSm, DSms and DST10m treatments

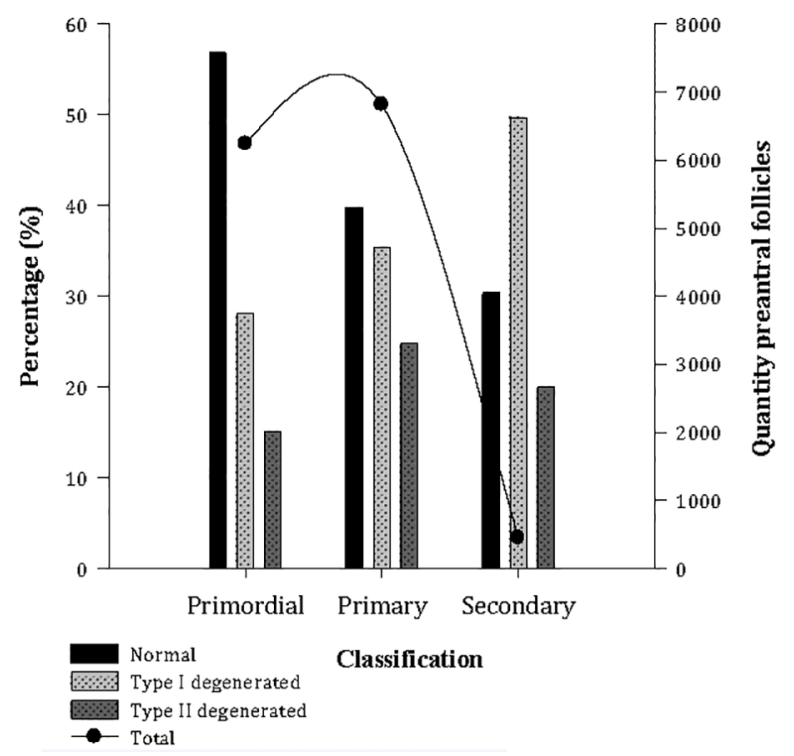

Fig.1. Classification of preantral follicles (a) per treatments and (b) developmental stage. Vitrification solution in uppercase; D = Dimethylsulfoxide; $\mathrm{S}=$ Sucrose; $\mathrm{T} 5=\alpha$-tocopherol $5 \mathrm{mmol} / \mathrm{L}$; $\mathrm{T} 10=\alpha$-tocopherol $10 \mathrm{mmol} / \mathrm{L}$. Thawed solution in lowercase; $\mathrm{m}=\mathrm{MEM} ; \mathrm{ms}=\mathrm{MEM}+$ sucrose.

with regard to the morphologically normal follicles (Table 2 ). Type I degenerative follicles did not differ from control and vitrification of treatments $(\mathrm{P}>0.05)$. The fresh control, DSm and DSms, had the lowest percentage of type II degenerative follicles $(\mathrm{P}>0.05)$ and between the vitrification treatments there were no differences in most treatments.

\section{Primordial follicles}

A total of 6,238 primordial follicles were analyzed and classified into normal, type I and II degenerated follicles $(3,544 ; 1,750$ and 944 , respectively). For the follicles with normal morphology there were no differences $(\mathrm{P}>0.05)$ 
Table 2. Morphological classification of preantral follicles in normal and degenerate (type I and II) with different vitrification treatments

\begin{tabular}{lccccccccc}
\hline \multicolumn{1}{c}{ Quality (\%) } & \multicolumn{7}{c}{ Treatments } \\
\cline { 2 - 9 } & Control & Dm & Dms & DSm & DSms & DST5m & DST5ms & DST10m & DST10ms \\
\hline Normal & $56.0^{\mathrm{a}}$ & $45.2^{\mathrm{bc}}$ & $43.6^{\mathrm{bc}}$ & $49.3^{\mathrm{ab}}$ & $55.9^{\mathrm{a}}$ & $43.0^{\mathrm{bc}}$ & $44.1^{\mathrm{bc}}$ & $49.6^{\mathrm{ab}}$ & $39.4^{\mathrm{c}}$ \\
Type I degenerated & $30.7^{\mathrm{b}}$ & $31.3^{\mathrm{ab}}$ & $32.9^{\mathrm{ab}}$ & $31.8^{\mathrm{ab}}$ & $30.0^{\mathrm{b}}$ & $34.8^{\mathrm{ab}}$ & $34.2^{\mathrm{ab}}$ & $29.8^{\mathrm{b}}$ & $37.1^{\mathrm{ab}}$ \\
Type II degenerated & $13.3^{\mathrm{c}}$ & $23.5^{\mathrm{a}}$ & $23.5^{\mathrm{ab}}$ & $18.9^{\mathrm{abc}}$ & $14.1^{\mathrm{bc}}$ & $22.2^{\mathrm{ab}}$ & $21.7^{\mathrm{ab}}$ & $20.6^{\mathrm{ab}}$ & $23.5^{\mathrm{a}}$ \\
\hline
\end{tabular}

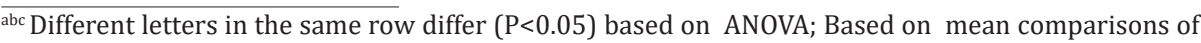
the Tukey's studentized range. Vitrification solution in uppercase; $\mathrm{D}=$ Dimethylsulfoxide; $\mathrm{S}=\mathrm{Sucrose}$; T5 = $\alpha$-tocopherol 5mmol $/ \mathrm{L} ; \mathrm{T} 10=\alpha$-tocopherol 10mmol $/ \mathrm{L}$. Thawed solution in lowercase; $\mathrm{m}=\mathrm{MEM}$; $\mathrm{ms}=\mathrm{MEM}+$ sucrose .

Table 3. Morphological classification (normal, type I and II degenerated) of preantral follicles in each developmental stage (primordial, primary and secondary) in different vitrification treatments

\begin{tabular}{|c|c|c|c|c|c|c|c|c|c|}
\hline \multirow{2}{*}{$\begin{array}{c}\text { Development } \\
\text { stage }\end{array}$} & \multicolumn{9}{|c|}{ Treatments } \\
\hline & Control & $\mathrm{Dm}$ & Dms & DSm & DSms & DST5m & DST5ms & DST10m & DST10ms \\
\hline \multicolumn{10}{|c|}{ Follicles classified as normal (\%) } \\
\hline Primordial & $69.0^{\mathrm{a} 1}$ & $51.4^{\mathrm{c} 1}$ & $50.0^{\mathrm{c} 1}$ & $60.0^{\mathrm{ab} 1}$ & $66.4^{\mathrm{a} 1}$ & $49.0^{c 1}$ & $53.9^{c 1}$ & $60.4^{\mathrm{ab} 1}$ & $52.8^{\mathrm{c} 1}$ \\
\hline Primary & $46.3^{\mathrm{a} 2}$ & $39.2^{\mathrm{cd} 2}$ & $39.6^{\mathrm{cd} 2}$ & $42.9^{\mathrm{abc} 2}$ & $44.7^{\mathrm{ab} 2}$ & $37.8^{\mathrm{d} 2}$ & $37.3^{\mathrm{d} 2}$ & $41.9^{\mathrm{bc} 2}$ & $31.8^{\mathrm{e} 2}$ \\
\hline Secondary & $26.9^{\mathrm{ab} 3}$ & $18.0^{\mathrm{b} 3}$ & $25.0^{\mathrm{ab} 2}$ & $42.6^{\mathrm{a} 2}$ & $38.1^{\mathrm{ab} 2}$ & $22.2^{\mathrm{bc} 3}$ & $26.7^{\mathrm{ab} 2}$ & $36.7^{\mathrm{ab} 2}$ & $35.9^{\text {ac2 }}$ \\
\hline \multicolumn{10}{|c|}{ Follicles classified type I degenerated (\%) } \\
\hline Primordial & $22.4^{\mathrm{c} 3}$ & $30.3^{\mathrm{b} 2}$ & $30.7^{\mathrm{b} 2}$ & $29.2^{\mathrm{b} 2}$ & $22.6^{\mathrm{c} 2}$ & $31.0^{\mathrm{ab} 3}$ & $30.8^{\mathrm{ab} 3}$ & $24.2^{\mathrm{c} 3}$ & $30.1^{\mathrm{b} 2}$ \\
\hline Primary & $36.2^{\mathrm{abc2}}$ & $31.5^{\mathrm{c} 2}$ & $34.0^{\mathrm{bc} 12}$ & $32.8^{\mathrm{bc} 12}$ & $37.2^{\mathrm{ab} 1}$ & $37.5^{\mathrm{ab} 2}$ & $35.8^{\mathrm{abc2}}$ & $38.3^{\mathrm{abc} 2}$ & $40.2^{\mathrm{a} 1}$ \\
\hline Secondary & $55.2^{\mathrm{a} 1}$ & $48.7^{\mathrm{ab} 1}$ & $50.0^{\mathrm{ab} 1}$ & $42.6^{\mathrm{ab} 1}$ & $57.1^{\mathrm{ab} 1}$ & $55.6^{\mathrm{a} 1}$ & $53.3^{\mathrm{ab} 1}$ & $57.1^{\mathrm{a} 1}$ & $35.9^{\mathrm{b} 12}$ \\
\hline \multicolumn{10}{|c|}{ Follicles classified type II degenerated (\%) } \\
\hline Primordial & $8.6^{\mathrm{c} 2}$ & $18.3^{\mathrm{a} 2}$ & $19.4^{\mathrm{a} 2}$ & $10.8^{\mathrm{c} 2}$ & $11.0^{\mathrm{c} 2}$ & $20.0^{\mathrm{a} 2}$ & $15.3^{\mathrm{b} 2}$ & $15.4^{\mathrm{b} 2}$ & $17.1^{\mathrm{b} 2}$ \\
\hline Primary & $17.5^{\mathrm{b} 1}$ & $29.3^{\mathrm{a} 1}$ & $26.4^{\mathrm{a} 1}$ & $24.3^{\mathrm{a} 1}$ & $18.1^{\mathrm{b} 1}$ & $24.7^{\mathrm{a} 1}$ & $26.9^{\mathrm{a} 1}$ & $19.8^{\mathrm{b} 1}$ & $28.0^{\mathrm{a} 1}$ \\
\hline Secondary & $17.9^{\mathrm{abcd} 1}$ & $33.3^{\mathrm{a} 1}$ & $25.0^{\text {abc12 }}$ & $14.8^{\mathrm{bcd} 12}$ & $4.8^{\mathrm{cd} 12}$ & $22.2^{\mathrm{abc12}}$ & $20.0^{\mathrm{abc} 12}$ & $6.2^{\mathrm{d} 2}$ & $28.2^{\mathrm{ab} 1}$ \\
\hline
\end{tabular}

abcde Different letters in the same row differ by the $\chi 2$ test $(\mathrm{P}<0.05)$; Different numbers in the column in each developmental stage differ by the $\chi 2$ test $(\mathrm{P}<0.05)$. Vitrification solution in uppercase; $\mathrm{D}=$ Dimethylsulfoxide; S = Sucrose; T5 = $\alpha$-tocopherol 5mmol $/ \mathrm{L} ; \mathrm{T} 10=\alpha$-tocopherol 10mmol $/ \mathrm{L}$. Thawed solution in lowercase; $\mathrm{m}=\mathrm{MEM}$; $\mathrm{ms}=\mathrm{MEM}+$ sucrose.

among the control (69\%), DSms (66.4\%), DSm (60\%) and DST10m (60.4\%). In the type I degenerated preantral follicles, the treatments DSms (22.6\%) and DST10m (24.2) did not differ $(\mathrm{P}>0.05)$ from the control $(22.4 \%)$, and the other vitrification treatments differed from control with larger percentages of degenerated follicles $(\mathrm{P}<0.05)$. For the preantral follicles with type II degenerated, the treatments Dm (18.3\%), Dms (19.4\%) and DST5m (20.0\%), the cell damage or follicular degeneration was higher $(\mathrm{P}<0.05)$ than in the control (8.6\%), DSm (10.8\%) and DSms (11.0\%) (Table 3).

\section{Primary follicles}

A total of 6,812 primary follicles were analyzed and classified into normal, type I and II degenerated $(2,714 ; 2,411$ and 1,687), respectively. For preantral follicles with normal morphology, there were no differences $(\mathrm{P}>0.05)$ among the treatments control (46.3\%), DSm (42.9\%) and DSms $(44.7 \%)$. Though in vitrification treatments, were observed no differences among DSm or DSMs and DST10m, Dm and Dms $(\mathrm{P}>0.05)$. The treatments that showed lower percentage of type II degeneration follicles were DSms and DST10ms without differences with the control $(\mathrm{P}>0.05)$ and differed the other vitrification treatments $(\mathrm{P}<0.05$; Table 3$)$.

\section{Secondary follicles}

A total of 450 secondary follicles was analyzed and classified into normal, type I and II degenerated (137; 223 and
90 , respectively). The morphological classes did not differ between control and vitrification treatments $(\mathrm{P}>0.05$; Table 3).

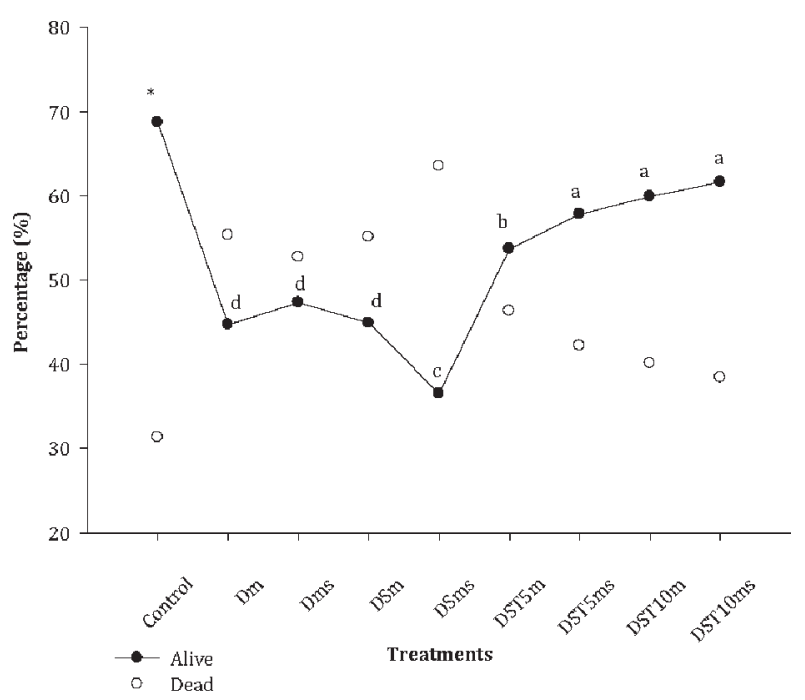

Fig.2. Viability of bovine preantral follicles. *Difference with the control; ${ }^{a, b, c, d}$ Letters indicate differences between treatments by the $\chi 2$ test $(\mathrm{P}<0.05)$. Vitrification solution in uppercase; $\mathrm{D}=$ Dimethylsulfoxide; $\mathrm{S}=$ Sucrose; T5 = $\alpha$-tocopherol $5 \mathrm{mmol} / \mathrm{L}$; $\mathrm{T} 10=\alpha$-tocopherol $10 \mathrm{mmol} / \mathrm{L}$. Thawed solution in lowercase; $\mathrm{m}=\mathrm{MEM} ; \mathrm{ms}=\mathrm{MEM}+$ sucrose. 


\section{Experiment II: Viability of bovine preantral follicles after vitrification}

The percentage of live preantral follicles in fresh control (68.7\%) was higher than in the vitrification treatments $(\mathrm{P}<0.05)$. Notwithstanding among the vitrification solutions, DST10s and DST10ms, was most effective in maintaining the viability of preantral follicles after vitrification (live follicles $59.9 \%$ and $61.6 \%$, respectively; Fig.2). The
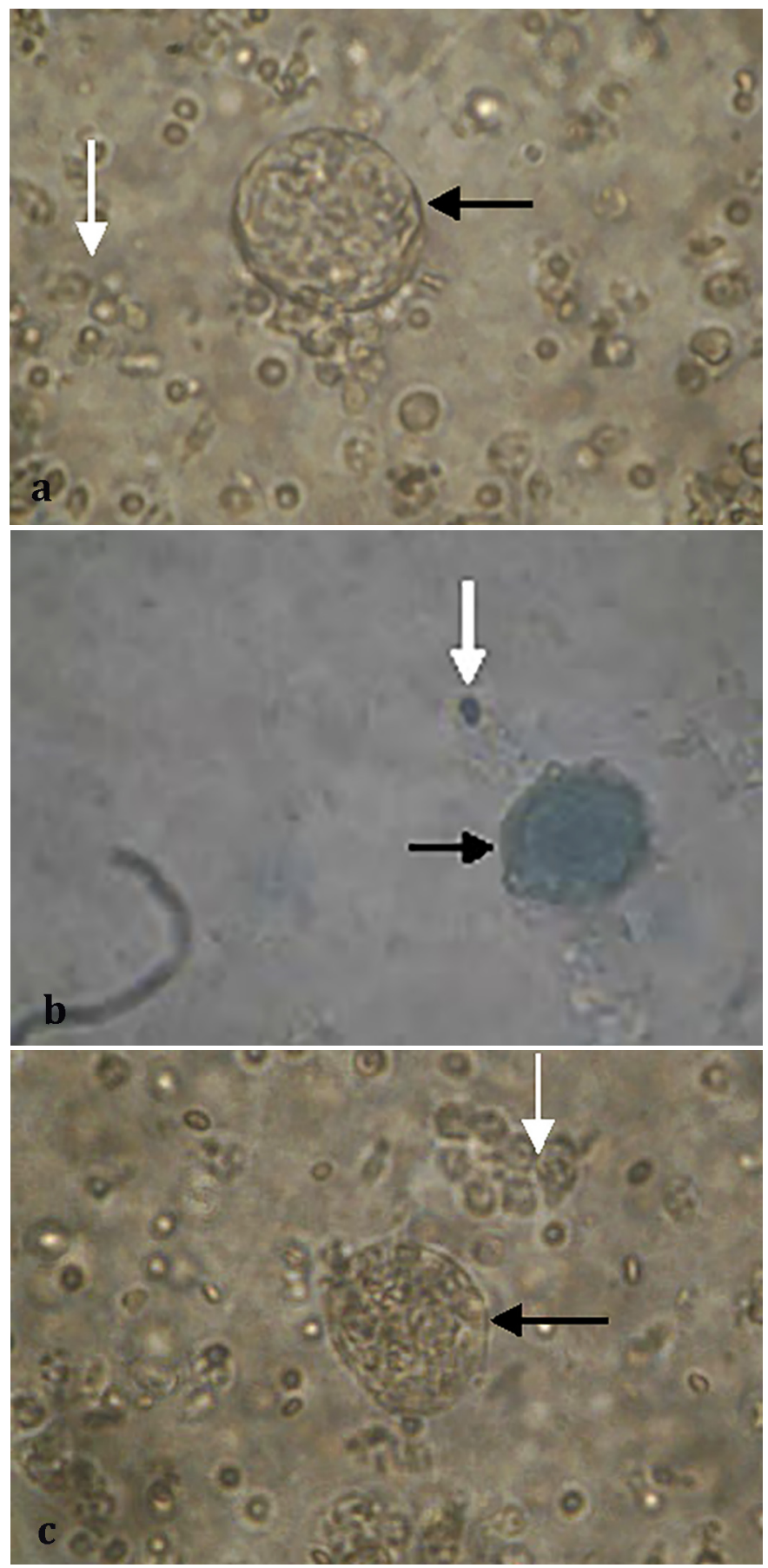

Fig.3. Isolated bovine preantral follicles stained with trypan blue. (a) Control; secondary preantral follicles - viable, (b) DSms; secondary preantral follicles - non-viable, and decreased ovarian stromal cells (c) DST10m; secondary preantral follicles - viable. Preantral follicles (black arrow) ovarian stromal cells (white arrow). Photographic camera Sony; obj.40x.
DSms treatment (36.5\%) was less effective in the percentages of viable follicles, differing from the other vitrification treatments $(\mathrm{P}<0.05$; Fig.3).

\section{Experiment I}

\section{DISCUSSION}

This study showed that bovine preantral follicles can be cryopreserved in the presence of: dimethylsulfoxide $5 \mathrm{~mol} / \mathrm{L}$, sucrose $0.5 \mathrm{~mol} / \mathrm{L}$ added or not of $\alpha$-tocopherol $10 \mathrm{mmol} / \mathrm{L}$, helping in maintaining the morphological quality of preantral follicles after vitrification. Several authors have studied the dimethylsulfoxide for cryopreservation protocols. Luna \& Munhoz (2008) successfully vitrified bovine ovarian tissue fragments, using dimethylsulfoxide (2.6 M). In caprine preantral follicles cryopreserved with dimethylsulfoxide, remained good conditions the granulosa and nucleus cells (Rodrigues et al. 2004). Castro et al. (2011) used dimethylsulfoxide as intracellular cryoprotectant agent and demonstrated its effectiveness in preserving caprine ovarian tissue. Similarly, different dimethylsulfoxide concentrations have been successfully used with ovarian tissue fragments of sheep, 3M (Santos et al. 2006b), 2.6 M (Castro et al. 2011) and 5M (Melo et al. 2008). Lucci et al. (2004) evaluated several cryoprotectants: ethylene glycol, propanediol and dimethylsulfoxide (1.5 or $3 \mathrm{~mol} / \mathrm{L})$ and found more pyknotic nuclear changes in bovine ovarian tissue fragments when using ethyleneglycol than with dimethylsulfoxide. In this study, the concentration of $5 \mathrm{~mol} / \mathrm{L}$ of dimethylsulfoxide showed up effective as intracellular cryoprotectant in the process of vitrification of bovine preantral follicles.

The extracellular cryoprotectants such as sucrose in the cryopreservation medium have been used in several species, with variable results. This study found that adding of sucrose $0.5 \mathrm{~mol} / \mathrm{L}$ to the vitrification solutions of bovine preantral follicles confers good morphology in granulosa cells and in oocytes. It was reported that sucrose resulted in water retention in the extracellular medium, preventing the entry of water quickest than the output of the intracellular cryoprotectant, reducing osmotic damage (Bacter et al. 2006). Thus, it is suggested that the beneficial effect of sucrose consists in its action as an osmotic buffer against cell stress during the addition and removal of permeable cryoprotectant agents (Newton et al. 1998). According to Salehnia et al. (2002), sucrose can be successfully used as an extracellular cryoprotectant of murine preantral follicles. Likewise, Santos et al. (2006b) reported the effectiveness of goat ovarian tissue cryopreservation with sucrose $0.5 \mathrm{~mol} / \mathrm{L}$. Melo et al. (2011) concluded that sheep preantral follicles can be successfully vitrified using dimethylsulfoxide $5 \mathrm{~mol} / \mathrm{L}$ when combined with $0.5 \mathrm{~mol} / \mathrm{L}$ sucrose. However, some authors believe that sucrose is not essential in the vitrification solution. Carvalho et al. (2011) tested the concentration of sucrose $0.5 \mathrm{~mol} / \mathrm{L}$ and concluded that there was an increase in the number of follicles in the presence of cytoplasmic retraction. Baird (1984) analyzed several aspects and concluded that the follicular cell, association of cryoprotectants, cryopreservation methods, as well as species, breed, and physiological stage should be taken into account in the cryopreservation procedure. 
Besides the intra or extracellular cryoprotectant, this study showed that the addition of $\alpha$-tocopherol $10 \mathrm{mmol} / \mathrm{L}$ in the vitrification solution provided optimal morphological preservation of preantral follicles. Thus can be seen that $\alpha$-tocopherol performs its function as an antioxidant and protective membrane on preantral follicles. Ferreira \& Matsubar (1997) affirmed that $\alpha$-tocopherol is highly effective because it removes reactive oxygen species before they cause injury. Different studies have successfully tested protective antioxidants; Carrascal et al. (2012) tested dimethylsulfoxide and ethyleneglycol with the antioxidant ascorbic acid and reported the best percentage of cells with morphological integrity after vitrification. On the other hand, in studies with males, $\alpha$-tocopherol added to the freezing solution of boar semen reduced the oxidative damage, improved sperm motility, preserved the integrity of the plasma and mitochondrial membranes (Satorre et al. 2007). Penitente-Filho et al. (2014) observed no differences in parameters of motility, vigor and hypoosmotic test in the thawed goat semen with $\alpha$-tocopherol. However, it is important to note that in studies using $\alpha$-tocopherol or other antioxidants these effects on preantral follicles cryopreservation are reduced. Therefore, further research on the effect of antioxidants is required to prove their effectiveness.

Santos et al. (2008) emphasized that cell damage is not only observed during vitrification, but also during the thawing process, when the cell metabolism is being re-established in the presence of toxic agents such as cryoprotectants. According to El-Naggar et al. (2006) the cryopreserved tissue should be thawed quickly in three successive washes, Although one washing is enough for thawing of embryos, isolated or in situ preantral follicles, three washing are recommended to remove traces of cryoprotective agents (Lima-Verde et al. 2009). Thus, in this study was performed rapid thawing and three washing in minimal essential medium or minimal essential medium with decreasing concentrations of sucrose $(0.50,0.25,0.0 \mathrm{~mol} / \mathrm{L})$. Nevertheless, the results showed generally no significant differences among the treatments when using minimal essential medium or minimal essential medium with sucrose as thawing medium. The data analysis of this study found that greater morphological changes were attributed to the vitrification solutions and not to thawing solutions.

The resistance of the different follicular stages (primordial, primary and secondary) on cryopreservation is still fairly debated and requires further elucidation (Luna \& Munhoz 2008). According to Santos et al. (2006a), primordial follicles are more resistant the process of cryopreservation. Confirming this assumption, in this study, primordial follicles showed a higher percentage of normal morphologically follicles than degenerates morphologically (I and II). Similarly, Carrascal et al. (2012) found that primordial and transitional follicles are more resistant than primary and secondary follicles to cooling procedures after vitrification. The result disagrees with Lucci et al. (2004), who found no differences in cryopreserved ovarian follicles of cattle in the primordial, primary and secondary classes. This greater tolerance of primordial follicles can be explained by several features that make them less vulnerable to cryoinjuries, such as: a small oocyte size, low metabolic rate, stage of the cell cycle, absence of pellucid zone and peripheral cortical granules, and a small amount of intra cytoplasmic lipid droplets (Shaw et al. 2000).

\section{Experiment II}

Cryopreservation can induces a disruption of the cell membrane, imperceptible by histological examination, resulting in the death of the follicles after thawing (Martinez-Madrid et al. 2004). Thus, cells with an apparently intact morphology may be non-viable and non-functional (Santos et al. 2006a). Therefore in experiment I, treatment DSms showed efficient morphologically in vitrification of preantral follicles, however, in experiment II it had the lowest follicular viability in comparison with other treatments of vitrification. Thus, in this study the percentage of viable follicles after vitrification, thawing and mechanical isolation of bovine ovarian tissue was highest in the treatment with DST10m (61.6\%). Similar results were obtained by Carrascal et al. (2012) with dimethylsulfoxide, ethyleneglycol and acid ascorbic (66\%) in the percentage of viable isolated bovine follicles. Luna et al. (2011) studied the cryoprotectants dimethylsulfoxide, ethyleneglycol and sucrose and she concluded that the percentage of follicle viability after exposure to cryoprotectants (64\%) was not different than after vitrification (66\%). In other species, follicle viability was $65 \%$ after vitrification and isolation of sheep ovarian tissue with cryoprotectants ethyleneglycol, sucrose and fetal bovine serum (Lunardi et al. 2012).

\section{CONCLUSION}

The association of dimethylsulfoxide, sucrose and $\alpha$-tocopherol $10 \mathrm{mmol} / \mathrm{L}$ thawed with minimal essential medium provides high survival rates and preserves morphological integrity during vitrification of bovine preantral follicles.

Acknowledgement.- The National Council for Scientific and Technological Development (CNPq), Coordination for Improvement of Higher Education Personnel (CAPES), the Foundation for Research Support of the State of Minas Gerais (FAPEMIG) and the Federal University of Viçosa (UFV). "Scholarship of CAPES/CNPq - IEL Nacional - Brazil".

\section{REFERENCES}

Bacter L.M.A.P., Madero J.I., Bacter C.L., Bacter M.F.L., Bacter L.A., Gómez C.M.D., Delgado L.G., Gómez C., LozanoJ.M. \& Reguero M.T. 2006. Basic points in cryopreservation. Revista Colombiana de Obstetricia y Ginecología 57:291-300.

Baird D.T. 1984. The ovary, p.91-114. In: Austin C.R. \& Short R.V. (Eds), Reproduction in Mammals. Vol.1. Cambridge University Press, Cambridge.

Basso A.C. \& Esper C.R. 2002. Isolamento e caracterização ultra-estrutural de folículos pré-antrais de vacas da raça Nelore (Bos taurus indicus). Braz. J. Vet. Res. Anim. Sci. 39:311-319.

Campebell B.K. \& Picton H.M. 1999. Oocyte storage. Curr. Obstetrics Gynecol. 9:203-209.

Carrascal E.L., Jimenez C.R., Azevedo J.L., Silveira R.G., Penitente-Filho J.M. \& Torres C.A.A. 2012. Association of cryoprotectants and ascorbic acid to cool and vitrify preantral bovine follicles. Anais IV International Symposium on Animal Biology of Reproduction, Campinas, SP, p.955. (Resumo) 
Carvalho A.A., Faustino L.R., Silva C.M., Castro S.V., Luz H.K., Rossetto R., Lopes C.A., Campello C.C., Figueiredo J.R., Rodrigues A.P. \& Costa A.P. 2011. Influence of vitrification techniques and solutions on the morphology and survival of preantral follicles after in vitro culture of caprine ovarian tissue. Theriogenology 76:933-941.

Castro S.V., Carvalho A.A., Silva C.M.G., Faustino L.R., Figueiredo J.R. \& Rodrigues A.P.R. 2011. Intracellular Cryoprotectant Agents: characteristics and use of ovarian tissue and oocyte cryopreservation. Acta Scientiae Veterinariae 39:957.

Demirci B., Lornage J., Salle B., Poirela M.P., Guerin J.F. \& Francka M. 2003. The cryopreservation of ovarian tissue: uses and indications in veterinary medicine. Theriogenology 60:999-1010.

El-Naggar M.M., Al-Mashat F.M., Elayat A.A., Sibiany A.R., Ardawi M.S. \& Badawoud M.H. 2006. Effect of thawing rate and post-thaw culture on the cryopreserved fetal rat islets: functional and morphological correlation. Life Sciences 78:1925-1932.

Ernst E., Bergholdt S., Jorgensen J.S. \& Andersen C.Y. 2010. The first woman to give birth to two children following transplantation of frozen/thawed ovarian tissue. Human Reproduction 25:1280-1281.

Ferreira A.L.A. \& Matsubar L.S. 1997. Radicais livres: conceitos, doenças relacionadas, sistema de defesa e estresse oxidativo. Revta Assoc. Méd. Bras. 43:61-68.

Hui Y.H., Comillon P., Legarretta I.G., Lim M.H., Murrell K.D. \& Nip W.K. 2004. Handbook of Frozen Foods, Food Science and Technology. Vol.133. Taylor and Francis, CRC Press, London, UK. 1293p.

Penitente-Filho J.M., Oliveira F.A., Jimenez C., Zolini A.M., Carrascal E., Dias J.C.O., Oliveira G.D., Silveira R.G., Silveira C.O. \& Torres C.A.A. 2014. Association of vitamin E with rapid thawing on goat semen. Anim. Sci. J. 14:1-5.

Lima-Verde I.B., Matos M.H.T., Bruno J.B., Martins F.S., Santos R.R., Báo S.N., Luque M.C.A., Vieira G.A.B., Silveira E.R., Rodrigues A.P.R., Figueiredo J.R., Oliveira M.A.L. \& Lima P.F. 2009. Effects of $\alpha$-tocopherol and ternatin antioxidants on morphology and activation of goat preantral follicles in vitro cultured. Arq. Bras. Med. Vet. Zootec. 61:57-65.

Lin T., Yen J., Kuo T., Gong K., Hsu K. \& Hsu T. 2008. Comparison of the developmental potential of 2-week-old preantral follicles derived from vitrified ovarian tissue slices, vitrified whole ovaries and vitrified/ transplanted newborn mouse ovaries using the metal surface method. BMC Biotechnology 8:38-50.

Lucci C.M., Kacinskis M.A., Rumpf R. \& Bao S.N. 2004. Effects of lowered temperatures and media on short-term preservation of zebu (Bosindicus) preantral ovarian follicles. Theriogenology 61:461-472.

Luna H.S. \& Munhoz A.L.R. 2008. Morfometria e número de células da granulosa de folículos ovarianos pré-antrais de bovinos (Bos indicus) preservados a $4^{\circ} \mathrm{C}$ em solução salina por diferentes períodos de tempo. Revta Bras. Saúde Prod. 9:1-6.

Luna H.S., Silva V.B. \& Abreu F.A. 2011. Viabilidade de folículos pré-antrais bovinos isolados de ovários após vitrificação. Ciênc. Anim. Bras. 12:693698.

Lunardi F.O., Araújo V.R., Faustino L.R., Carvalho A.A., Gonçalves R.F.B., Bass C.S., Báob S.N., Olázia K.P., Campello N.C.C., Figueiredo J.R. \& Rodrigues A.P.R. 2012. Morphologic viability and ultrastructural analysis of vitrified sheep preantral follicles enclosed in ovarian tissue. Small Rumin. Res. 107:121-130.

Martinez-Madrid B., Dolmans M.M., Van Langendonckt A., Defrère S. \& Donnez J. 2004. Freeze-thawing intact human ovary with its vascular pedicle with a passive cooling device. Fertility and Sterilely 82:13901394.
Melo M.A.P., Bao S.N., Rodrigues A.P.R., Silva J.R.V. \& Figueiredo J.R. 2008. Preservation of bovine preantral follicle viability and ultra-structure after cooling and freezing of ovarian tissue. Anim. Reprod. Sci. 108:309318.

Melo M.A.P., Oskam I.C., Celestino J.J.H., Carvalho A.A., Castro S.V., Figueiredo J.R., Rodrigues A.P. \& Santos R.R. 2011. Adding ascorbic acid to vitrification and IVC medium influences preantral follicle morphology but not viability. Reprod. Domest. Anim. 46:742-745.

Newton H., Fisher J., Arnold J.R.P., Pegg D.E., Faddy M.J. \& Gosden R.G. 1998. Permeation of human ovarian tissue with cryoprotective agents in preparation for cryopreservation. Human Reproduction 13:376-380.

Oktay K., Newton H. \& Aubard Y. 1998. Cryopreservation of immature human oocytes and ovarian tissue: an emerging technology. Fertility and Sterility 354:1-7.

Rodrigues A.P.R., Amorim C.A., Costa S.H.F., Matos M.H.T., Santos R.R. \& Lucci C.M. 2004. Cryopreservation of caprine ovarian tissue using dimethylsulphoxide and propanediol. Anim. Reprod. Sci. 84:211-227.

Rodrigues A.P.R., Castro S.V., Lunardi F.O. \& Figueiredo J.R. 2014. Avanços na criopreservação de tecido ovariano de cabras e ovelhas. Acta Veterinaria Brasilica 8:284-291.

Rodrigues A.P.R., Faustino L.R., Celestino J.J.H. \& Figueiredo J.R. 2010. Progress in Caprine and Ovine Preantral Follicles Cryopreservation. Acta Scientiae Veterinariae 38:417-447.

Romero F.J., Bosch-Morell F., Romero M.J., Jareño E.J., Romero B., Marín N. \& Romá J. 1998. Lipid peroxidation products and antioxidants in human disease. Environ. Health Perspectives 106:1229-1234.

Salehnia M., Moghadam E.A. \& Velojerdi M.R. 2002. Ultrastructure of follicles after vitrification of mouse ovarian tissue. Fertility and Sterility 78:644-645.

Santos R.R., Celestino J.J.H., Lopes C.A.P., Melo M., Rodrigues A.P.R. \& Figueiredo J.R. 2008. Criopreservação de folículos ovarianos pré-antrais de animais domésticos. Revta Bras. Reprod. Anim. 32:9-15.

Santos R.R., Rodrigues A.P.R., Costa S.H.F., Matos M.H.T., Celestino J.J.H., Saraiva M.V.A., Melo M.A.P. \& Figueiredo J.R. 2006b. Teste de toxicidade e criopreservação de folículos pré-antrais ovinos isolados utilizando Glicerol, Etilenoglicol, Dimetilsulfóxido e Propanodiol. Braz. J. Vet. Res. Anim. Sci. 43:250-255.

Santos R.R., Rodrigues A.P.R., Costa S.H.F., Silva J.R.V., Matos M.H.T., Lucci C.M., Báo S.N., Van den Hurk R. \& Figueiredo J.R. 2006a. Histological and ultrastructural analysis of cryopreserved sheep preantral follicles. Anim. Reprod. 91:249-263.

Satorre M.M., Breininger E., Beconi M.T. \& Beorlegui N.B. 2007. Alpha-Tocopherol modifies tyrosine phosphorylation and capacitation-like state of cryopreserved porcine sperm. Theriogenology 68:958-965.

Shaw J.M., Oranratnachai M. \& Trounson A.O. 2000. Fundamental criobiology of mammalian oocytes and ovarian tissue. Theriogenology 53:5972.

Souza M.F., Tomé A.R. \& Rao V.S. 1999. Inhibition by the bioflavonoid ternatin of aflatoxin B1- induced lipid peroxidation in rat liver. J. Pharmacol. Pharmacotherapeutics 51:125-129.

Yeoman R.R., Wolf D.P. \& Lee D.M. 2005. Coculture of monkey ovarian tissue increases survival after vitrification and slow-rate freezing. Fertility and Sterility 83:1248-1254.

Wang X., Falcone T., Attaran M., Goldber M.J., Agarwa A. \& Sharm R.K. 2002. Vitamin C and vitamin E supplementation reduce oxidative stress induced embryo toxicity and improve the blastocyst development rate. Fertility and Sterility 78:1272-1277. 